\title{
Small College Library Directors: Getting in the Door and Surviving on the Job
}

\section{Julie O’Keeffe}

This article reports findings from a 1996 survey that examined job preparedness of library directors at four-year colleges in twelve midwestern states. The survey measured: (1) qualifications possessed at the time each person obtained his or her first director's position; and (2) the skills and abilities directors felt were essential to surviving and doing well in their positions. One hundred fifty-eight directors returned questionnaires for a response rate of 84 percent. Participants in the 1995-1996 College Library Director Mentor Program also supplied a list of essential skills for the first year in a new position.

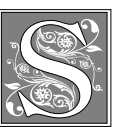

mall college library directors are a unique breed of service professionals. They are called upon to perform a host of diverse duties, from answering reference questions to providing leadership on campus. Furthermore, their roles have evolved over time as they are continually challenged by new environments. Directors' responsibilities also vary greatly from institution to institution, depending on a host of factors related to each particular institution.

It is important that the library profession continue to identify and prepare talented individuals to direct our small college libraries. However, the unique nature of the role may make it difficult for aspiring directors to know what to expect and whether they are prepared adequately for the job. In a 1983 study, Terrence F. Mech reported that:
[Small college] libraries are often a direct reflection of their directors' skills and abilities. Since library directors tend to respond to problems and challenges based on their own previous experience, education, and background, these factors are important to consider. While there is a small but growing body of knowledge about college librarianship, very little is known about the men and women who direct the nation's many small college libraries. ${ }^{1}$

How can someone best prepare to fill this role? What level of experience and qualifications is desirable going into a director's position? What skills enable directors to survive and do well in their positions?

One method to determine a probable level of desired qualifications is to look at the individuals already holding posi-

Julie O'Keeffe is Reference/Instruction Librarian at Marquette University; e-mail: okeeffej@marquette.edu. 
tions as directors. What degree of professional experience did each of these people possess when they obtained their position? How many years of experience did they have? At how many institutions and in how many positions did they gain this experience? Did they have experience supervising other librarians? Did they have much administrative experience? Had they ever published anything? Had they held many leadership positions in professional library organizations prior to obtaining their position as director?

\section{Almost half of the directors held graduate degrees in addition to an MLS.}

For aspiring directors of small college libraries, understanding the level of qualifications needed to compete for a director's position is only half the process. It also is important to understand what it takes to survive on the job and to succeed in a director's position. There are a number of "softer" skills and abilities that a director must possess in order to perform well in his or her new role. These are skills librarians may not have learned in library school, such as negotiation, personnel, communication, and the ability to articulate a vision. Such skills and abilities are extremely important in smaller institutions where faculty and administrators must work closely together and where relationships play a key role in the ability to get things done. It is an art to run a successful library, advocate its needs, and gain adequate support on campus while maintaining good relations both internally and externally.

This paper reports on a 1996 survey of small college library directors that measured both the qualifications possessed at the time each person obtained his or her first director's position and the skills and abilities each felt were essential to surviving and doing well in the position. The author also contacted directors who participated in the 1995-1996 College Library Director Mentor Program, established through the Leadership Committee of ACRL's College Library Section. Each individual was asked to supply a list of essential skills for the first year in a new position. The information obtained from these two groups of directors is intended to serve as a guide for aspiring directors and to take some of the guesswork out of preparing for their future.

\section{Literature Review}

A literature review failed to identify any survey research between 1985 and 1996 that addressed the issue of preparedness, in terms of qualifications and skills, for small college library director positions. A limited time frame was chosen for the review with the notion that any survey data covering prior years would be of insufficient value in today's library environment. The author identified a number of articles published over the past ten years that used survey data to profile directors or librarians in one way or another. These profiles include measurements of a number of qualifications for specific groups of librarians in various types of organizations. In terms of directors, however, the profiles examined the entirety of their professional lives, not just the portion completed at the time they became directors. Therefore, it was impossible to learn from those studies the level of qualifications possessed at the time each director obtained his or her position. However, it was possible to glean other relevant data from two studies.

Mech conducted survey research in 1983 that profiled directors in seven midwestern states. ${ }^{2}$ The directors were located at institutions accredited by the North Central Association of Colleges and Schools (NCACS) and which had an enrollment of fewer than 3,500 students. He found that women directed 45 percent of the libraries at these colleges. Almost half of the directors held graduate degrees in 
addition to an MLS. One out of four directors had worked only in their present library, and 29 percent were internal candidates. Seventy percent of the directors were native to their region, and 25 percent were employed by their alma mater. Mech noted that the latter situation correlated to institutions with smaller enrollments. Most of the data above point to a narrow set of experiences for a portion of the group studied in terms of knowledge of more than one institution or geographic region. The remainder of Mech's data relevant to the current study do not allow comparison due to the time period examined in measuring each variable (entirety of professional life versus time prior to obtaining first director's position).

In a second study in 1989, Mech examined the managerial role of library directors at institutions in nine midwestern states which were accredited by the NCACS or Southern Association of Colleges \& Schools and which had enrollments of more than 500 students. He found that:

\section{. . . baccalaureate and community college directors spend more time with faculty and students, spend less time as negotiators and decision makers, and see technical skills [as] more important to their jobs than do other directors. Perhaps their situa- tions demand ... these directors to 'tend to the library' and perform more as professional librarians than as managers. ${ }^{3}$}

Most of the other survey research done between 1985 and 1996 on librarian qualifications either focused on populations not useful for comparison to the population of the current study or reported results from research conducted prior to 1985.

\section{Methodology}

The author designed a mail questionnaire to measure specific small college library director qualifications and to obtain a laundry list of skills that directors consider essential to their job performance. Seven variables were used to measure qualifications, all limited to the time period prior to gaining their first director's position: (1) years of full-time professional library experience; (2) number of full-time professional positions; (3) number of institutions at which these positions were held; (4) years of full-time library administrative experience; (5) years of experience supervising professional librarians; (6) publication record; and (7) number of committee and officer positions in professional library organizations. These variables were chosen as measurements of qualifications over other possible measurements because they seem to be those normally considered when filling director positions.

The three-page questionnaire included thirty questions organized under six headings: "Personal Information," "Education," "Work Experience," "Publication Record," "Professional Activities," and "Job Effectiveness." It first asked respondents to record the year in which they obtained their first director's position, allowing for the possibility that a director no longer may be in his or her first position. The questionnaire then asked respondents to answer each subsequent qualification-related question in terms of activities and experience prior to that year.

The essential skill portion of the questionnaire fell under "Job Effectiveness." To obtain a laundry list of essential skills, respondents were instructed to "Please identify the most important abilities or 'things' you believe are essential to surviving and doing well in a director's position." Examples were provided, consisting of "patience," "ability to handle personnel problems," and "ability to look at the big picture."

The questionnaire was pretested in February 1996 with thirty-two library directors in Tennessee and Arkansas. In 
April 1996, it was sent to library directors at every primarily four-year college in twelve midwestern states: Illinois, Indiana, Iowa, Kansas, Michigan, Minnesota, Missouri, Nebraska, North Dakota, Ohio, South Dakota, and Wisconsin. Midwestern states were selected because of the author's familiarity with the region and because the Midwest is home to many four-year colleges. Four-year colleges were defined as those classified by the Carnegie Foundation as Baccalaureate I or Baccalaureate II. One hundred ninety-five institutions fit these classifications. Six institutions did not employ a library director currently, leaving 189 institutions in the survey group. Ninety percent of these institutions had enrollments of fewer than 2,000 students, thereby allowing the study to maintain its intended focus on "small" colleges. All the directors at the 189 institutions received a questionnaire. Those recipients who did not respond initially were sent a follow-up postcard. Finally, one week after the postcard, a second copy of the questionnaire was mailed, along with a stick of gum, to all remaining nonrespondents. Ultimately, 158 directors responded, for a response rate of 84 percent.

The author then contacted the 1995-1996 participants of the ACRL/CLS mentoring program for new college library directors. Each of the fifteen directors received the questionnaire described above, with one change: The "essential skill" question was rewritten to solicit a list of skills the directors felt were essential to surviving and doing well in the first year of a director's position. Thirteen of the fifteen participants responded to the questionnaire.

Initially, the author was uncertain as to how much of the data from the mentoring group would be used in the subsequent analysis. The main goal in soliciting participation was to learn which skills the participants considered essential to the first year in a director's position. This portion of the data proved useful, and was examined on its own and then compared to skill-related data from the other group. However, the mentoring group's responses regarding qualifications were excluded from any data analysis for two reasons: (1) The individuals in the group did not meet the criteria for inclusion in the main population chosen for the study; and (2) the small size of the group did not allow for any useful analysis of qualifications on its own.

The questionnaire data collected from the main population of the study were tabulated using SPSS. Composite averages were calculated for the data, including the seven qualification-related variables. Averages then were recalculated for the seven variables in terms of other factors to determine whether a correlation existed between the respondent's level of qualification and the following: (1) gender; (2) age at the time the respondent obtained his or her first director's position; (3) enrollment size of the institution where the respondent obtained his or her first director's position; (4) whether the respondent was an internal or external candidate; (5) whether the respondent was an alumnus of the institution; (6) the decade in which the respondent obtained her or his first director's position; and (7) Carnegie classification of current institution.

The essential skills identified by the main population of the study were categorized either according to the functional area with which the skill is associated (management, personnel, communication, planning, and budget) or by grouping similar skills together (campuswide relationships, service orientation, perspective, personal attributes, and miscellaneous skills). Respondents contributed a total of 648 items, distilled and "de-duplicated" down to 135 items.

The skills identified by participants in the mentoring program then were compiled and compared to the above sets of skills. Fifty-four items were contributed, distilled to thirty-two items. 


\section{Results}

\section{General Profile}

A general profile of the respondents, excluding participants in the mentoring program, includes the following data:

- Eighty-one respondents $(53 \%)$ were male, and seventy-one ( $47 \%$ ) were female.

- The average age of respondents when they obtained their first director's position was 38 .

- The average enrollment size of respondents' institutions was 1,351. Most enrollments $(80 \%)$ ranged from 400 to 2,000 .

- Almost half $(46 \%)$ of all respondents were internal candidates for their first director's position.

- One out of five respondents $(20 \%)$ was an alumnus of the institution where he or she first served as library director.

- Thirty-three percent of respondents obtained their first director's position prior to 1981; 45 percent obtained their first position between 1981 and 1990; and 22 percent obtained their first position between 1991 and 1996.

- Twenty-five percent of respondents now direct libraries at institutions classified as Baccalaureate I institutions; the other 75 percent serve at Baccalaureate II institutions.

- Three out of four respondents $(76 \%)$ are still employed in their first director's position. Of the directors who moved on to other jobs, the average length of service in the first director's position was five years.

- Every respondent holds an MLS.

- Thirty-eight percent of respondents hold at least one master's degree beyond the MLS; most (86\%) earned the second degree prior to obtaining their first director's position.

- Fourteen percent of respondents hold doctorates. Two-thirds of this group $(64 \%)$ earned a doctorate prior to obtaining their first director's position, and half of those who hold doctoral degrees pur-

\begin{tabular}{lc|}
\multicolumn{2}{c|}{ TABLE 1A } \\
Qualifications of First-time Directors \\
\hline \hline & $\begin{array}{c}\text { All } \\
\text { Respondents }\end{array}$ \\
\hline $\begin{array}{l}\text { Percent of main population } \\
\text { Years of full-time professional } \\
\text { library exp. }\end{array}$ & $100 \%$ \\
$\begin{array}{l}\text { No. of full-time professional } \\
\text { library positions }\end{array}$ & 8.2 \\
$\begin{array}{l}\text { No. of institutions where } \\
\text { positions were held }\end{array}$ & 1.8 \\
$\begin{array}{l}\text { Years of full-time library } \\
\text { administrative exp. }\end{array}$ & 3.2 \\
$\begin{array}{l}\text { Years of experience supervising } \\
\text { librarians }\end{array}$ & 2.3 \\
$\begin{array}{l}\text { Percent of group that had } \\
\text { published }\end{array}$ & $43 \%$ \\
$\begin{array}{l}\text { Percent of group that had held } \\
\text { positions }\end{array}$ & $49 \%$ \\
\hline
\end{tabular}

sued a career teaching at the college level before becoming a librarian.

- Forty percent of respondents had earned undergraduate degrees in either English or history, with another 14 percent in education.

\section{Professional Work Experience}

Table 1A shows the work experience of respondents prior to obtaining their first director's position, including the following averages:

- 8.2 years of full-time professional (post-MLS) library experience;

- experience in 2.1 full-time professional library positions;

- professional, full-time experience at 1.8 institutions;

- 3.2 years of full-time library administrative experience;

- 2.3 years of experience supervising professional librarians.

A different look at the data gives a more interesting picture. Almost 20 percent of first-time directors possessed one year of professional library experience or less when they assumed their positions. Thirty-two percent of directors had held only one professional job prior to gain- 
ing their first director's position, and 14 percent had not held any professional jobs. Half the respondents possessed no full-time library administrative experience, although administrative experience was defined as "at least 75 percent of your

\section{Sixty-five percent of first-time directors had never supervised professional librarians when they assumed their position.}

duties involving paperwork, as opposed to hands-on provision of service." Considering that (1) service is the major component of small college library positions and (2) the organizational structure normally is composed of only two tiers, it is not surprising that respondents had had little experience in concentrated administrative work. Finally, 65 percent of first-time directors had never supervised professional librarians when they assumed their position. This also is most likely attributable to the flat organizational structure.

\section{Publication Record}

Prior to obtaining their first director's position, 43 percent of the respondents had had at least one item accepted for publication. Specifically:

- One out of five respondents (20\%) had published articles in peer-reviewed library journals.

- One out of seven respondents (14\%) had published articles in peer-reviewed nonlibrary journals.

- One out of four respondents (25\%) had published articles elsewhere.

- Fourteen respondents (9\%) had written chapters of books.

- Seven respondents (5\%) had been the sole author of a book.

- Two respondents (less than $2 \%$ ) had coauthored one or more books.

- Four respondents (less than 3\%) had been the primary editor of one or more books.

\section{Professional Activities}

Prior to obtaining their first director's position, almost half the respondents (49\%) had held an officer or committee position in a professional library organization. Specifically:

- One out of four respondents (25\%) had held positions at a substate level.

- One out of three respondents (34\%) had held positions at the state level.

- One out of five respondents $(20 \%)$ had held positions at the national level.

\section{Qualification Differences between Subgroups}

Certain subgroups of respondents were noticeably more qualified than others. The author made comparisons by examining work experience, publication record, and involvement in professional organizations within the following seven sets of subgroups: men versus women; respondents who were thirty-eight years old or younger when they obtained their first director's position versus those who were thirty-nine or older; respondents whose institutions had enrollments of fewer than 600 students versus enrollments between 601 and 1,100 versus enrollments greater than 1,100 ; internal versus external candidates; alumni versus nonalumni; respondents who obtained their first position prior to 1981 versus those who obtained it between 1981 and 1990 versus those who obtained it between 1991 and 1996; and directors who currently work at Baccalaureate I institutions versus those who currently work at Baccalaureate II institutions.

Qualifications were compared within each set of subgroups using a three-step process. First, averages were calculated for each variable in each subgroup. The resulting figure for each variable in one subgroup then was compared to the same variable in the opposing subgroup. For example, men had an average of 6.11 years of experience compared to the women's average of 4.9 years. Therefore, the men had 25 percent more experience 


\begin{tabular}{|c|c|c|c|c|}
\hline \multicolumn{5}{|c|}{$\begin{array}{c}\text { TABLE 1B } \\
\text { Qualifications of First-time Directors }\end{array}$} \\
\hline & \multicolumn{2}{|c|}{ Affiliation } & \multicolumn{2}{|c|}{ Age } \\
\hline & Alumni & $\begin{array}{l}\text { Non- } \\
\text { alumni }\end{array}$ & $\begin{array}{l}38 \text { and } \\
\text { Younger }\end{array}$ & $\begin{array}{l}39 \text { and } \\
\text { Older }\end{array}$ \\
\hline Percent of main population & $20 \%$ & $80 \%$ & $53 \%$ & $47 \%$ \\
\hline $\begin{array}{l}\text { Years of full-time professional } \\
\text { library exp. }\end{array}$ & 6.3 & 8.6 & 5.0 & 11.8 \\
\hline $\begin{array}{l}\text { No. of full-time professional } \\
\quad \text { library positions }\end{array}$ & 1.3 & 2.3 & 1.6 & 2.7 \\
\hline $\begin{array}{l}\text { No. of institutions where } \\
\text { positions were held }\end{array}$ & 1.1 & 1.9 & 1.4 & 2.2 \\
\hline $\begin{array}{l}\text { Years of full-time library } \\
\text { administrative exp. }\end{array}$ & 0.9 & 3.8 & 1.6 & 4.9 \\
\hline $\begin{array}{l}\text { Years of experience supervising } \\
\text { librarians }\end{array}$ & 0.3 & 2.9 & 0.8 & 4.1 \\
\hline $\begin{array}{l}\text { Percent of group that had } \\
\text { published }\end{array}$ & $23 \%$ & $48 \%$ & $38 \%$ & $48 \%$ \\
\hline $\begin{array}{l}\text { Percent of group that had held } \\
\text { positions }\end{array}$ & $32 \%$ & $54 \%$ & $38 \%$ & $62 \%$ \\
\hline
\end{tabular}

than the women. Finally, a mean was calculated as the percent difference in total qualifications between subgroups. For example, men possessed 32 percent more qualifications than women did.

All seven sets of subgroups showed differences in qualifications within their set. Following are descriptions of these differences:

Alumni versus nonalumni: This set of subgroups showed the greatest difference. Nonalumni were three times more qualified (222\% more qualified) than alumni. As table 1B shows, nonalumni had 2.3 more years of work experience than alumni (37\% more), 1.0 additional positions (77\% more), over four times the number of years of administrative experience ( $322 \%$ more), and nearly ten times the amount of experience supervising librarians ( $867 \%$ more). They also were more than twice as likely to have published ( $48 \%$ compared to $23 \%$ of alumni) and 69 percent more likely to have served in a committee or officer positions ( $54 \%$ compared to $32 \%$ of alumni).

Older candidates versus younger candidates: The next greatest difference in level of qualifications correlated to age at the time respondents obtained their first director's position. Keep in mind that the study did not look at respondents' current age but, rather, at their age at the time they obtained their position. Respondents' ages ranged from twenty-four to sixty-eight when they became directors. Although it may seem apparent that older job candidates would have more qualifications than younger ones, this is not necessarily the case. It is important to consider that some directors may have pursued other careers prior to joining the library profession and thus would have fewer years of experience when they obtained their first director's position than would be expected otherwise. Despite this possibility, the data showed that candidates who were thirty-nine or older were more than twice as qualified (139 percent more qualified) than those who were thirty-eight or younger. As table 1B shows, their biggest advantage was in terms of supervisory experience: Older candidates had an average of 4.1 years of supervisory experience when they obtained their first director's position, as compared to 0.8 years for younger candidates. It ap- 


\begin{tabular}{|c|c|c|c|c|c|c|}
\hline \multicolumn{7}{|c|}{$\begin{array}{c}\text { TABLE 1C } \\
\text { Qualifications of First-time Directors } \\
\end{array}$} \\
\hline & \multicolumn{3}{|c|}{ Enrollment Size } & \multicolumn{3}{|c|}{$\begin{array}{c}\text { Decade in Which } \\
\text { Position Was Obtained }\end{array}$} \\
\hline & $\begin{array}{l}600 \text { and } \\
\text { Fewer }\end{array}$ & $\begin{array}{l}601- \\
1,100\end{array}$ & $\begin{array}{c}\text { Greater } \\
\text { than } 1,100\end{array}$ & $\begin{array}{c}\text { Before } \\
1981\end{array}$ & $\begin{array}{c}1981- \\
1990 \\
\end{array}$ & $\begin{array}{c}1991- \\
1996\end{array}$ \\
\hline Percent of main population & $33 \%$ & $33 \%$ & $33 \%$ & $33 \%$ & $45 \%$ & $22 \%$ \\
\hline $\begin{array}{l}\text { Years of full-time professional } \\
\text { library exp. }\end{array}$ & 7.1 & 7.5 & 9.6 & 5.3 & 10.2 & 8.3 \\
\hline $\begin{array}{l}\text { No. of full-time professional } \\
\text { library positions }\end{array}$ & 1.6 & 2.1 & 2.7 & 1.8 & 2.2 & 2.3 \\
\hline $\begin{array}{l}\text { No. of institutions where } \\
\text { positions were held }\end{array}$ & 1.4 & 1.8 & 2.1 & 1.5 & 1.9 & 1.8 \\
\hline $\begin{array}{l}\text { Years of full-time library } \\
\text { administrative exp. }\end{array}$ & 2.9 & 2.4 & 4.5 & 1.7 & 4.1 & 3.5 \\
\hline $\begin{array}{l}\text { Years of experience supervising } \\
\text { librarians }\end{array}$ & 1.5 & 1.9 & 3.7 & 0.9 & 2.7 & 3.8 \\
\hline $\begin{array}{l}\text { Percent of group that had } \\
\text { published }\end{array}$ & $32 \%$ & $43 \%$ & $53 \%$ & $36 \%$ & $45 \%$ & $48 \%$ \\
\hline $\begin{array}{l}\text { Percent of group that had held } \\
\text { positions }\end{array}$ & $28 \%$ & $64 \%$ & $60 \%$ & $34 \%$ & $54 \%$ & $64 \%$ \\
\hline
\end{tabular}

pears that older candidates simply may have waited longer before obtaining their first director's position and accumulated more qualifications in the process.

Large enrollment versus small enrollment: Enrollment was the third best predictor of qualifications. Respondents who obtained their first director's position at institutions with enrollments of more than 1,100 students were more qualified at the time they assumed the position than directors at institutions with enrollments of between 601 and 1,100 (40\% more qualified) and directors at institutions with enrollments of fewer than 600 (77\% more qualified) (table 1C). Specifically, they possessed significantly more administrative and supervisory experience than directors at medium-sized schools ( $88 \%$ and 95\% more, respectively).

Decade in which position was obtained: The next best predictor of qualifications was the decade in which each respondent obtained his or her first position. As seen in table 1C, although respondents who became directors between 1991 and 1996 had only slightly higher qualifications when they assumed their position than those who obtained positions between 1981 and 1990 (5\% higher qualifications), they had almost twice the qualifications of those who obtained positions prior to 1981 (93\% higher qualifications). Directors who obtained their positions prior to 1981 possessed less than one fourth of the supervisory experience and approximately half the administrative experience possessed by the 1990s group. The same group also held positions in professional organizations at approximately half the rate of the 1990s group.

Baccalaureate I versus Baccalaureate II: Directors who currently work at Baccalaureate I institutions possessed qualifications 53 percent higher than those at Baccalaureate II institutions (table 1D). They had more years of experience ( $41 \%$ more), had held more positions $(30 \%$ more), had more than twice as much experience supervising librarians (147\% more), and had published and held positions in professional organizations at a noticeably higher rate $(53 \%$ and $58 \%$ higher, respectively). 


\begin{tabular}{|c|c|c|c|c|c|c|}
\hline \multicolumn{7}{|c|}{$\begin{array}{c}\text { TABLE 1D } \\
\text { Qualifications of First-time Directors }\end{array}$} \\
\hline & \multicolumn{2}{|c|}{$\begin{array}{c}\text { Carnegie } \\
\text { Classification }\end{array}$} & \multicolumn{2}{|c|}{ Gender } & \multicolumn{2}{|c|}{ Candidacy Status } \\
\hline & $\begin{array}{l}\text { Baccalau- } \\
\text { reate I }\end{array}$ & $\begin{array}{l}\text { Baccalau- } \\
\text { reate II }\end{array}$ & Male & Female & Internal & External \\
\hline Percent of main population & $25 \%$ & $75 \%$ & $53 \%$ & $47 \%$ & $46 \%$ & $54 \%$ \\
\hline $\begin{array}{l}\text { Years of full-time professional } \\
\text { library exp. }\end{array}$ & 10.4 & 7.4 & 8.6 & 7.7 & 8.6 & 7.8 \\
\hline $\begin{array}{l}\text { No. of full-time professional } \\
\text { library positions }\end{array}$ & 2.6 & 2.0 & 2.2 & 2.0 & 1.9 & 2.3 \\
\hline $\begin{array}{l}\text { No. of institutions where } \\
\text { positions were held }\end{array}$ & 2.0 & 1.7 & 1.8 & 1.7 & 1.6 & 1.9 \\
\hline $\begin{array}{l}\text { Years of full-time library } \\
\text { administrative exp. }\end{array}$ & 3.7 & 3.0 & 3.3 & 3.0 & 2.9 & 3.4 \\
\hline $\begin{array}{l}\text { Years of experience supervising } \\
\text { librarians }\end{array}$ & g $\quad 4.2$ & 1.7 & 2.9 & 1.7 & 2.0 & 2.6 \\
\hline $\begin{array}{l}\text { Percent of group that had } \\
\text { published }\end{array}$ & $58 \%$ & $38 \%$ & $48 \%$ & $37 \%$ & $39 \%$ & $46 \%$ \\
\hline $\begin{array}{l}\text { Percent of group that had held } \\
\text { positions }\end{array}$ & $68 \%$ & $43 \%$ & $52 \%$ & $46 \%$ & $49 \%$ & $50 \%$ \\
\hline
\end{tabular}

Men versus women: Men were 22 percent more qualified than women (table 1D). Men had 12 percent more years of full-time professional library experience, 10 percent more full-time professional library positions, 10 percent more administrative experience, and 71 percent more experience supervising professional librarians. Forty-eight percent of men had published, compared to 37 percent of women. Fifty-two percent of men had held officer or committee positions in professional library organizations compared to 46 percent of women.

External versus internal candidates: External candidates had 14 percent higher qualifications than internal candidates (table 1D). However, this does not mean that internal candidates were necessarily at a disadvantage when they sought their positions. Rather, it is possible each was the most qualified person in his or her pool of candidates. In terms of specific qualifications, external candidates fell short of internal candidates in one area: years of experience in profession. Exter- nal candidates possessed 7.8 years of experience compared to 8.6 years for internal candidates ( $9 \%$ less). In all other areas, external candidates ranked anywhere from 17 to 30 percent higher.

\section{In terms of specific qualifications, external candidates fell short of internal candidates in one area: years of experience in profession.}

\section{Essential Skills}

Members of the study's main population were generous in contributing a list of skills, abilities, and other "things" they felt were essential to surviving and doing well in a director's position. Table 2 shows the percent of items mentioned by category. The largest categories were personal attributes ( $29 \%$ of all items), followed by management skills (15\%), personnel skills (13\%), communication skills $(11 \%)$, and campuswide relationships $(10 \%)$. Less-mentioned categories included planning skills $(6 \%)$, perspective, 


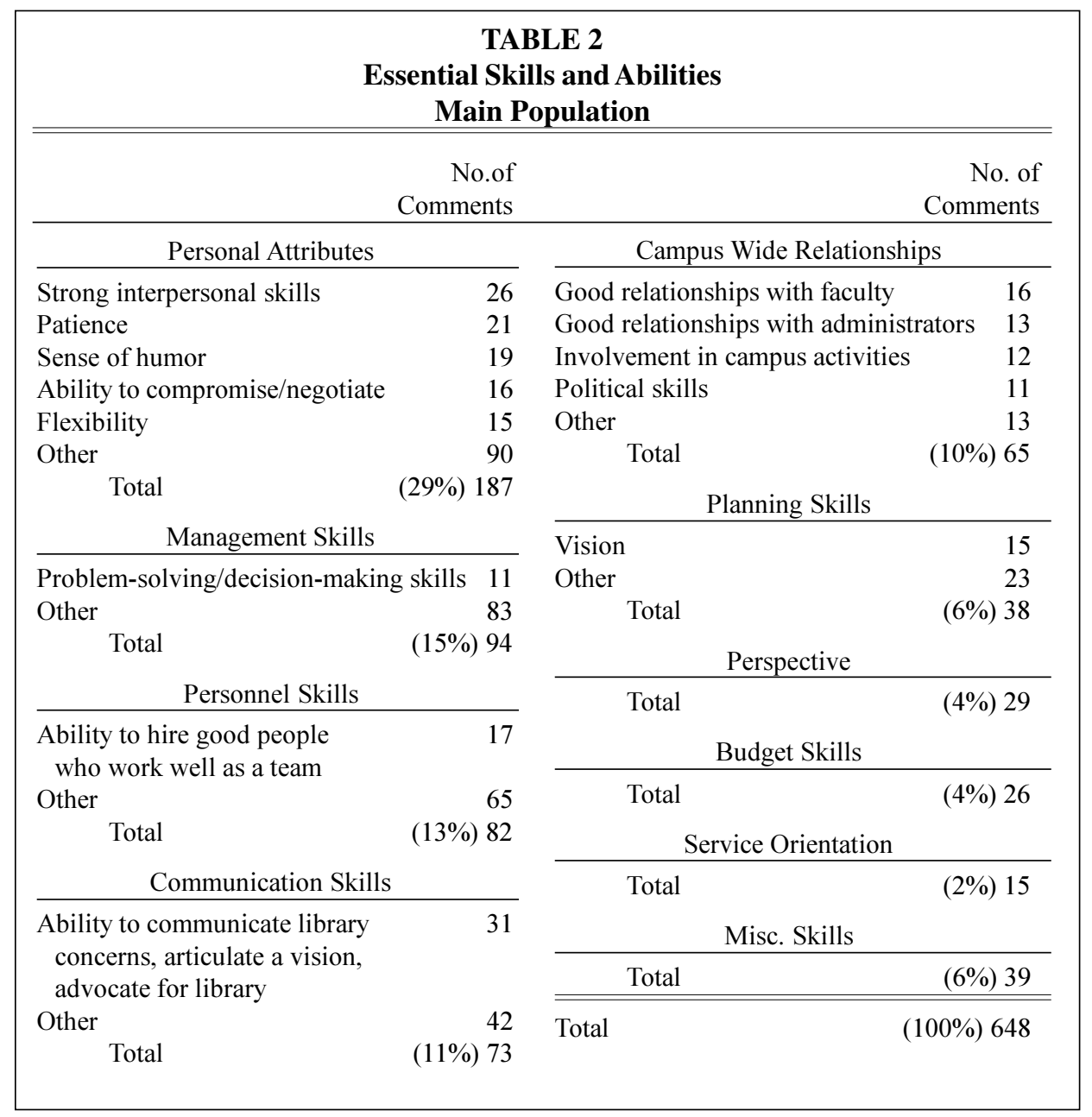

or ability to see the big picture (4\%), budget skills $(4 \%)$, and a service orientation $(2 \%)$.

Strong interpersonal skills, patience, sense of humor, ability to compromise/ negotiate, and flexibility claimed the top positions (in that order) when it came to personal attributes. Although these were only five of the forty items contributed as personal attributes, they comprised more than half of all comments in this category.

A number of items in other categories also were widely cited by respondents. The most-often cited skills within selected categories were: problem-solving/deci- sion-making skills $(12 \%$ of all comments in management category); ability to hire good people who work well as a team (21\% of all comments in personnel category); ability to communicate library concerns, articulate a vision, advocate for the library $(42 \%$ of all comments in communication category); good relationships with faculty and administrators (when combined, $45 \%$ of all comments in campuswide relationships category); and vision ( $40 \%$ of all comments in planning skills category).

Members of the ACRL/CLS mentoring program also provided a valuable list of skills, abilities, and other "things" they considered 


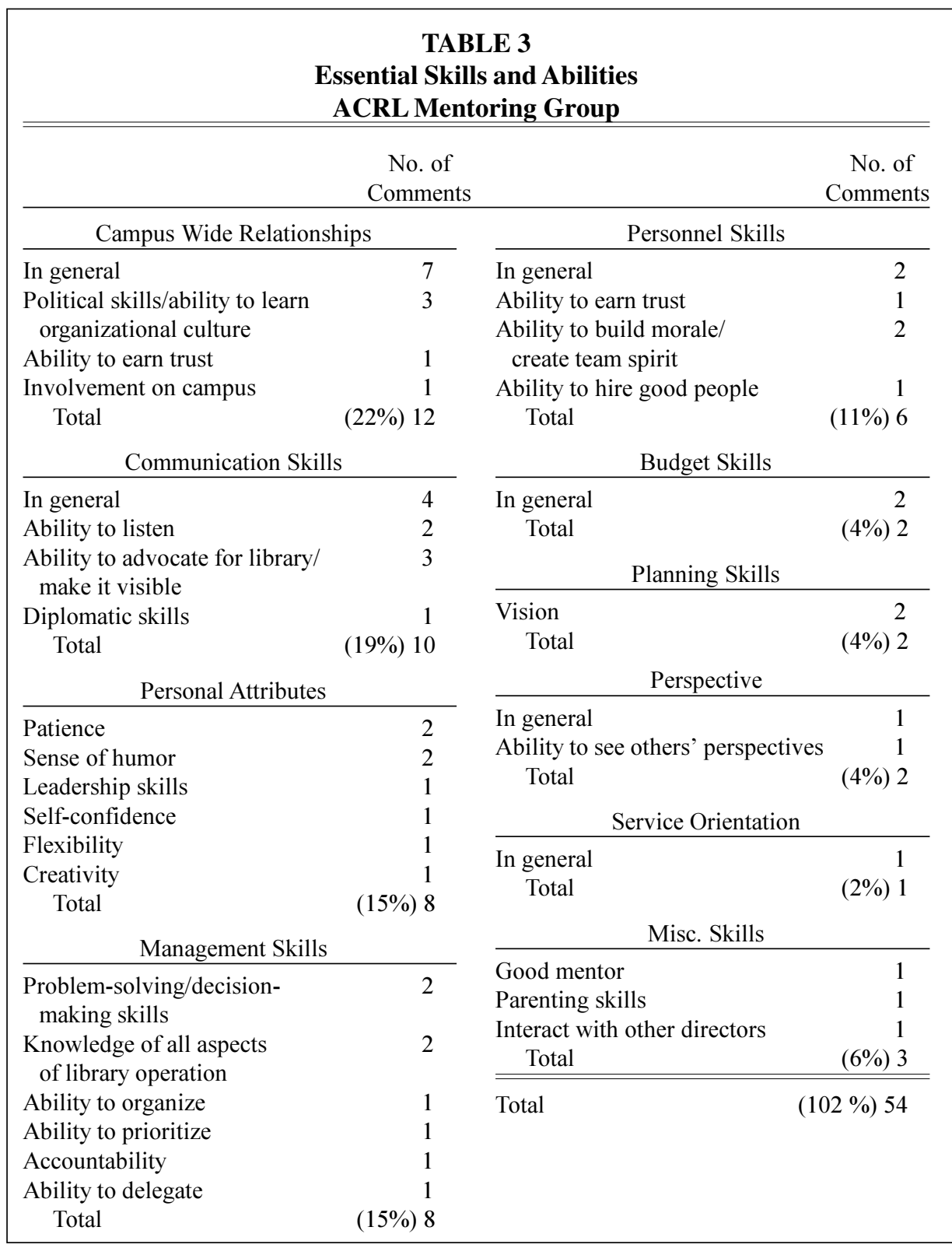

essential to surviving and doing well in the first year as a director. As shown in table 3, the largest categories were campuswide relationships ( $22 \%$ of all items), communication skills (19\%), personal attributes $(15 \%)$, management skills $(15 \%)$, and personnel skills (11\%). Lessmentioned categories included plan- ning skills (4\%), perspective, or ability to see the big picture (4\%), budget skills $(4 \%)$, and a service orientation ( $2 \%)$. Independent of category, the items cited most frequently were: good relationships with faculty and administrators (cited seven times), communication skills (cited four times), ability to gauge the political 
climate and understand the organizational culture (cited three times), and ability to advocate for the library (cited three times). On the whole, participants in the mentoring group did not repeat each other's contributions often; only twelve of the thirty-two items were mentioned by more than one person.

Skills contributed by the mentoring group resemble those contributed by the study's main population in a broad sense. Although ranked differently, the top five categories are the same for both groups of respondents (campuswide relationships, communication skills, personal attributes, management skills, and personnel skills). Conversely, the remaining four categories (budget skills, planning skills, perspective, and service orientation) rank lowest for both groups. Individual skills that stand out in both sets of responses include good relationships with faculty and administrators, and ability to advocate for the library.

Anecdotal experience has shown the
author that younger directors often
are found at smaller schools and
older directors at larger schools.

\section{Discussion}

\section{Qualifications}

The results of the study indicate that there is a noticeable correlation between level of qualifications and the factors of age, size of enrollment, and whether the director is an alumnus. Anecdotal experience has shown the author that younger directors often are found at smaller schools and older directors at larger schools. This would be expected due to the exposure given to, and role played by, the director in a larger setting. It is true that there are many elite schools that are very small in enrollment size and employ very qualified, experienced directors. But there also are hundreds of small, religiously-affiliated schools around the country that are less prestigious. These schools are likely to offer lower salaries than more prestigious schools and thus would be expected to attract less competitive candidates. By nature, those candidates often would be younger. Ultimately, it is not surprising to find a noticeable correlation between level of qualifications and age or size of enrollment.

However, it is more difficult to explain the correlation between level of qualifications and whether the director is an alumnus. The fact that a person is an alumnus should not thereby deem that he or she is less qualified than other directors. There is something in the hiring practice of certain institutions that accounts for this situation. It is possible that when interviewing candidates, even if someone with alumnus status is slightly less qualified than other candidates, institutions choose the alumnus over the others.

The only alarming data from the survey were that almost 20 percent of firsttime directors had one year of professional library experience or less when they assumed their position and that 14 percent had not held any professional jobs when they assumed their first director's position. It is difficult to imagine that these individuals would possess the knowledge and skills necessary to perform well. It is possible that these positions are at institutions that have very small library collections and limited services, and thus a prior grounding in providing full-scale services is not necessary or required. The institutions could be the educational facilities for religious organizations and might value a candidate's ties to the denomination more than his or her professional qualifications.

\section{Skills}

It is apparent that some very important skills contribute to successfully serving at a library's helm. Respondents were very sincere in their belief that they could not succeed without skills and qualities such as strong interpersonal skills, patience, sense of humor, and 
ability to hire good people who work well as a team. The other two extremely important skills were ability to form good relationships with faculty and administrators and ability to articulate a vision and communicate library concerns to administrators.

The ranking of essential skills for firstyear directors was interesting. It makes sense that campuswide relationships ranked as the highest category for this group of directors; cultivating these relationships is critical to the library's success. However, it is less obvious why personal attributes eventually percolate to the top, as seen in the list of skills for directors who are in subsequent years of their position. Perhaps it is because directors are tested over time and their ability to handle various situations is tied directly to their personal attributes.

This study does not attempt to analyze the data obtained on essential skills. The list of skills is intended primarily to help aspiring directors to become aware of the skills they may need to improve. At a minimum, it helps make future librarians aware of the skills they will likely be expected to have.

Two concerns should be addressed regarding the list of skills included in this study. First, the author recognizes that the skills listed here may not differ from those needed at a larger institution. No attempt has been made to compare or contrast skills required at different-size institutions. Second, no attempt has been made to prioritize the skills by measure of importance, although the frequency of mention by the respondents of certain skills would seem to indicate that they may play a more prominent role in a director's ability to perform.

\section{Additional Comments from Respondents}

The final area of interest from the study were respondents' additional comments. The best quote from the questionnaires describes the role of a small college library director in a nutshell:
I think the most important skill is the ability to juggle-to work around constant interruptions. To smile at the student who needs help just when your creative juices are flowing; or the faculty member who needs to talk about resources for the department when your budget request is due tomorrow.

This quote demonstrates the patience, flexibility, and interpersonal skills that respondents frequently cited as essential skills.

Other comments demonstrated the degree of satisfaction derived from, and variety involved in, directing a small college library. One respondent indicated he enjoyed his work ". . . because I like to do a variety of things. I can still have some amount of 'hands on' as well as running the show. Aspiring directors need to be versatile and flexible to cope with the many tasks you are called on to do." Flexibility also was illustrated through respondents' examples of various nontraditional duties such as moving furniture, dusting, cleaning up a roof leak, and fixing the time clock.

The factors of limited financial and human resources also were apparent. One respondent indicated: "Before I became director, our library did a national search for a director who ideally would have administrative experience.... However, our institution has difficulty attracting someone of that caliber because of low pay." Other respondents commented on small staff size. One person stated: "I had only been a librarian for one and a half years when I was promoted to the position of director. We are a small library with only two professional staff; therefore, my responses may not be typical." This person did not realize that his or her situation is not uncommon.

In addition, politics was the topic of many comments. Respondents indicated the need to gauge the political climate and act within it. One person said: "I have seen several directors defeated by their lack of political ability." 
Two final comments of interest included: "One's qualifications get the interview. After that it seems to be chemical," and "Train under an excellent director. Observe closely."

Participants in the mentoring program made some useful comments regarding their first year as director. One stated: "I think no matter how well you prepare yourself for the position, there will always be surprises at the reality, especially with the first directorship." Another said: "The best advice I'd give a prospective director is to make sure you've had enough of the 'hands-on librarian' work so that administration appeals to you. In other words, make sure you're ready for something totally different." Finally, someone offered: "Know that you will make mistakes and that they will be more visible than before [becoming a director]. Learn from them and move on quickly; don't dwell on the past."

\section{Conclusion}

The items presented in this report are important in preparing for a position as director at a small college. Although progressive work experience, publication, and leadership in professional organizations often are the focus of professional development pursuits, of equal importance are the softer skills and abilities essential to a library's day-to-day administration.

Advertisements for director's positions at smaller institutions often include a statement on the ability to function well in a small, collegial environment. Institutions placing these announcements understand they cannot afford to overlook the importance of softer skills. The institutions that hire only on the basis of more measurable qualifications may achieve a certain degree of prestige in the public eye, but it may be at the expense of the director's ability to perform well in his or her new environment.

The ideal situation is to hire directors who have both hard qualifications and softer skills. Although it might prove somewhat difficult to attract such people to smaller institutions, there are a number of librarians who prefer a smaller environment. Often they are the products of small colleges themselves and seek to have the same personal impact on today's students they experienced as undergraduates. The library profession should encourage and support these individuals in preparing for this role.

\section{Notes}

1. Terrence F. Mech, "Small College Library Directors of the Midwest," Journal of Academic Librarianship 11 (Mar. 1985): 8.

2. Ibid., 8-13.

3. Terrence F. Mech, "Academic Library Directors: A Managerial Role Profile," College \& Research Libraries 51 (Sept. 1990): 425. 